\title{
GROWTH AND MORTALITIES OF THE PINK-SHRIMP Farfantepenaeus brasiliensis LATREILLE, 1970 AND F. paulensis PÉREZ-FARFANTE 1967 IN SOUTHEAST BRAZIL
}

\author{
LEITE JR., N. O. ${ }^{1}$ and PETRERE JR., M. ${ }^{2}$ \\ ${ }^{1}$ Projeto TAMAR, Avenida Paulino Mueller, 1111, Jucutucuara, CEP 29040-715, Vitória, ES, Brazil \\ ${ }^{2}$ Departamento de Ecologia, UNESP, Av. 24-A, 1515, Bela Vista, C. P. 199, CEP 13506-900, Rio Claro, SP, Brazil \\ Correspondence to: Nilamon de Oliveira Leite Júnior, Projeto TAMAR, Avenida Paulino Mueller, 1111, Jucutucuara, \\ CEP 29040-715, Vitória, ES, Brazil, e-mail: nilamontamar@yahoo.com.br
}

Miguel Petrere Júnior, Departamento de Ecologia, UNESP, Av. 24-A, 1515, Bela Vista, C. P. 199, CEP 13506-900, Rio Claro, SP, Brazil, e-mail: mpetrere@ @rc.unesp.br.

Received July 7, 2004 - Accepted December 15, 2004 - Distributed May 31, 2006

(With 2 figures)

\begin{abstract}
From July, 1999 until July, 2001 data from the pink-shrimp Farfantepenaeus brasiliensis Latreille, 1970 and F. paulensis Pérez-Farfante, 1967 fishery were collected from trawling by the fishing fleet based in Santos/Guarujá-SP. Growth and mortalities of these species were studied. F. brasiliensis and F. paulensis have longevity of 2 years and growth estimates of $\mathrm{L} \infty=29.0 \mathrm{~cm}$ and $\mathrm{k}=1.24$ year $^{-1}$ for $F$. brasiliensis and $\mathrm{L} \infty=27.5 \mathrm{~cm}$ and $\mathrm{k}=1.34$ year $^{-1}$ for $F$. paulensis. Females reach bigger lengths than males in both species. Natural mortalities (M) were 1.80 and 1.90 year $^{-1}$ and fishing mortalities (F) were 4.7 and 6.8 year $^{-1}$ for F. brasiliensis and F. paulensis, respectively. Survival rates are $\mathrm{S}=0.15 \%$ and $0.02 \%$ for $F$. brasiliensis and F. paulensis, respectively, which are usually low values for shrimps.
\end{abstract}

Keywords: tropical marine fishery, pink-shrimp, Farfantepenaeus, growth, mortalities, Brazil.

\section{RESUMO}

\section{Crescimento e mortalidades do camarão-rosa Farfantepenaeus brasiliensis Latreille, 1970 e F. paulensis Pérez-Farfante, 1967 no Sudeste do Brasil}

De Julho de 1999 a Julho de 2001, foram coletados dados das pescarias comerciais do camarão-rosa Farfantepenaeus brasiliensis Latreille, 1970 e F. paulensis Pérez-Farfante, 1967, relativos à frota pesqueira de arrasto, sediada em Santos (SP). Estimativas dos parâmetros de crescimento e de mortalidades foram calculadas. Farafantepenaeus brasiliensis e $F$. paulensis são espécies de crescimento rápido e vida curta, com longevidade de 2 anos ( $\mathrm{L} \infty=29,0 \mathrm{~cm}$ e k $=1,24$ ano $^{-1}$ para F. brasiliensis; $\mathrm{L} \infty=27,5 \mathrm{~cm}$ e $\mathrm{k}=1,34$ ano $^{-1}$ para $F$. paulensis). As fêmeas atingem tamanhos maiores que os machos para ambas espécies. As mortalidades naturais foram estimadas em $\mathrm{M}=1,80 \mathrm{ano}^{-1}$ e $1,90 \mathrm{ano}^{-1}$ e as mortalidades por pesca $\mathrm{F}=4,7$ ano $^{-1}$ e 6,8 ano $^{-1}$ para $F$. brasiliensis e $F$. paulensis, respectivamente. As taxas de sobrevivência foram calculadas em $S=0,15 \%$ para $F$. brasilensis e $S=0,02 \%$ para $F$. paulensis, valores usualmente baixos para camarões.

Palavras-chave: pescarias marinhas industriais tropicais, camarão-rosa, Farfantepenaeus, crescimento, mortalidades, Brasil. 


\section{INTRODUCTION}

\section{The shrimp fishery history}

Exploiting shrimps from the superfamily Penaeoidea is an old and widespread activity in many sub-tropical and tropical areas of the world, especially in coastal areas of various countries (Garcia \& Le Reste, 1986). Starting in the 1950s, shrimp exploitation in SE Brazil has increased dramatically due to the development of a specialized industrial fishery. At the end of the 1970s, the international market became highly favorable in terms of commercializing this resource, because of its high prices due to an increased demand from rich countries. As a consequence of this increase, nearly all shrimp stocks in the world are now highly exploited, and many species can even be considered as being over-exploited. There is a paucity of basic knowledge concerning population dynamics of the most exploited species, so that any effort towards a rational exploitation of the stocks is a difficult task (Garcia \& Le Reste, 1986; Isaac et al., 1992).

The shrimp fishing production in Brazil occupies the $12^{\text {th }}$ place in the world, and $6^{\text {th }}$ place in the production of shrimps of the Penaeidae family (FAO, 1998). In 1984 and 1985, shrimps represented about $6 \%$ in weight and approximately $24 \%$ of the economic value of the total fishing production in the Southeastern and South regions (Valentini et al., 1991). In the data set about pink-shrimps (F. brasiliensis and $F$. paulensis) in the Southeastern and South regions of Brazil, from 1965 to 1999 the maximum total attained $16,028 \mathrm{t}$ in 1972 and the minimum in 1998 with 2,008 $\mathrm{t}$. The total production of the pink-shrimp increased until 1972 decreasing afterwards with peaks in 1979 (12,780 t) and $1985(12,511 \mathrm{t})$, reaching extremely low values in 1994, 1998 and 1999 (2,100, 2,008 and 2,207 $\mathrm{t}$ respectively) (Valentini et al., 1991; D'Incao et al., 2002).

Nowadays, the exploitation of pink-shrimps (Farfantepenaeus brasiliensis e $F$. paulensis) in South and Southeast Brazil is controlled by the Brazilian Environmental Agency (IBAMA), with nearly 400 trawlers being officially allowed to exploit this resource. These trawlers have a wooden hull, averaging $18.5 \mathrm{~m}$ length, $55 \mathrm{t}$ gross tonnages and 246 HP. In southeast Brazil, the state of São Paulo fishing fleet represents $59.0 \%$ of all the trawlers, followed by those from Santa Catarina (20\%), Rio de Janeiro (18\%), Espírito Santo (3\%) and Rio Grande do Sul (0.4\%) states (IBAMA, 1997).

\section{Biology of the species}

Farfantepenaeus brasiliensis Latreille, 1970, is widely distributed, ranging from Cape Hatteras (North Carolina, USA) down to Rio Grande do Sul (South Brazil). This species is most abundant in Cabo Frio (RJ) and in Santos and Cananéia (SP) (Zenger Jr. \& Agnes, 1977). Farfantepenaeus paulensis Pérez-Farfante, 1967, has a more restricted distribution, ranging from Ilhéus (BA) to northeastern Argentina. On the continental shelf, two areas of high abundance were ecognized: one in Santa Catarina and the other between Santos and São Sebastião Island, state of São Paulo. In Rio Grande do Sul, however, the fishery is restricted to juveniles and sub-adults in the interior of Patos lagoon (D’Incao, 1995; Zenger Jr. \& Agnes, 1977).

Both species have the same characteristic life cycles as the Penaeoidea superfamily. Reproduction occurs in the ocean, on the continental shelf at depths between 30 to $100 \mathrm{~m}$. The eggs are benthonic, the larval phases and the first post-larvae are planktonic and oceanic. From the $6^{\text {th }}$ sub-stage of post-larvae the shrimps penetrate in estuarine areas, of lower depths and higher temperatures and start to have benthonic habits. In these areas, the post-larvae become juveniles and pre-adults and start to be exploited by the coastal/artisanal fishing fleet. They complete their life cycle when these juveniles and pre-adults migrate to the ocean to finish developing and reproducing and joining the adult stock (Iwai, 1973; Valentini et al., 1991; Isaac et al., 1992).

The aim of this study was to investigate growth and mortality rates by sex using a length frequency analysis for the two species of pink-shrimp Farfantepenaeus brasiliensis and Farfantepenaeus paulensis in order to give basic information for further stock management.

\section{MATERIAL AND METHODS}

From June, 1999 to June, 2001, with the exceptions of March/April, 2000 and March to May in 2001, the ban period, length measurements, as well as fishery data, were obtained in the main fishery terminals in the municipality of Santos. This city is located on the southern coast of the state São 
Paulo, and has the highest number of landings from the industrial fishery of the pink-shrimp in the south and southeast regions of Brazil. This is mostly due to the fact that the trawlers from the state of São Paulo are the only ones that still maintain the pinkshrimp as their target species, whereas the fleets from other States definitely operate a multispecific capture (Perez et al., 2001 unpublished report; D'Incao et al., 2002).

In 76 samples collected during the period, a total of 6,861 pink shrimps from both species were individually processed in order to obtain data on the total (Lt) and carapace (Lc) length, in millimeters, and total weight $(\mathrm{Wt})$, in grams, observing the sex and visually assessing the female maturity stage based on size, color and form of gonads for both species (Neiva et al., 1971). The differentiation between the two species was carried out by observing that $F$. brasiliensis has a rounded spot on the $3^{\text {rd }}$ and $4^{\text {th }}$ tergo-lateral plates in the abdomen (Pérez-Farfante, 1988). The total length was measure with a special shrimpruler, graded in millimeters, as the distance from the rostral extremity to the telson extremity. The carapace length was measured with a digital caliper $(0.01 \mathrm{~mm})$ from the post-orbital angle to the dorsal posterior margin of the carapace (Isaac et al., 1992; Ruffino, 1991). The weight was quantified with a precision $(0.01 \mathrm{~g})$ balance. Length measurements were grouped in size classes $(\mathrm{mm})$ and the monthly frequencies per class were calculated. The sex was determined by the presence of a petasma or thelycum for males and females, respectively.

Biometric relationships between the total weight (Wt) and total length (Lt), for both sexes during 1999/2001, were calculated for both species on a logarithmic scale. The relationship between length calculated in arithmetic scale. All regressions between sexes were compared using a linear regression comparison test. The growth coefficient "b" of Wt/Lt Relationship was compared with 3 (isometric growth) using a "t" test (Snedecor \& Cochran, 1967; Zar, 1996).

Length frequency data were analyzed using the software package FiSAT (FAO/ICLARM Stock Assessment Tools), which is part of the analytical tools of the programs LFSA and COMPLEAT ELEFAN (Gayanilo et al., 1994; Sparre \& Venema, 1997). Growth data for both species were analyzed, jointly or separately, using a modal progression applied to the length frequency distributions. The von Bertalanffy growth function was used as a growth model (von Bertalanffy, 1938).

The parameters of the growth curve (of von Bertalanffy) were estimated according to the following methods: ELEFAN-I (Pauly \& David, 1981), to estimate the parameters $L_{\infty}$ and $k$ from the von Bertalanffy growth equation; PowellWetherall (Powell, 1979), which use the length frequency data to estimate $\mathrm{L} \infty$ and $\mathrm{Z} / \mathrm{K}$, and Bhattacharya (1967) to identify the mean length per cohort, together with the Gulland and Holt method (Gulland \& Holt, 1959) and the non-linear iterative method (Allen, 1966) for estimates of $\mathrm{L} \infty$, $\mathrm{k} \mathrm{e} \mathrm{t}_{0}$. The methods used in this study to estimate the growth parameters showed a certain degree of subjectivity when being carried out. Among all of the obtained estimates from the different methods, we opted for the Elefan-I values as the most appropriate, due to the fit index (Rn) that reduces the degree of subjectivity of the estimates. Thus, the values obtained through this program were used in all of the subsequent models that were required as input data values of the growth parameters.

Seven methods were used to estimate the total mortality rate (Z): Hoening's empirical method (1984 apud Sparre \& Venema, 1997), which related the maximum individual longevity to its mortality; the methods of Beverton \& Holt (1956), Ault \& Ehrhardt (1991) and Ssentongo \& Larkin (1973), which calculate mortality from the mean length when captured; Powell-Wetherall's method (Powell, 1979) to estimate Z/k; Pauly's method of a catch curve (1983) and Jones \& van Zalinge's method (1981), carried out by FiSAT. The methods used in this study to estimate total mortality showed similar values and then a mean value of the methods was calculated for the two species.

The natural mortality rate (M) was estimated by the Pauly empirical (1980) formula, which relates $\mathrm{M}$ to $\mathrm{k}, \mathrm{L} \infty$ and the temperature using a multiple regression analysis. The mortality rate per fishery was obtained by the formula: $\mathrm{F}=\mathrm{Z}-\mathrm{M}$.

\section{RESULTS}

\section{Biometrical relationships}

The minimum and maximum total lengths (cm) found in the industrial fishery were 7.9 and 21.9 for males and 8.7 and 26.0 for females of 
F. brasiliensis; 8.9 and 18.0 (males) and 9.1 and 23.6 (females) for F. paulensis. Biometrical relationships between the total weight $(\mathrm{Wt})$ and total length $(\mathrm{Lt})$, and between the Lt and carapace length (Lc) for both sexes during 1999/2001 are presented in Figs $1 \mathrm{a}$ and $1 \mathrm{~b}$. The regressions (WtxLt), in log-log scale were compared using a test for linear regression comparisons (Snedecor \& Cochran, 1967; Zar, 1996), were significantly different $(\mathrm{p}<0.01)$ between sexes for both species, a rather expected result as the sample sizes are so large.

The growth coefficient (b) of the $\mathrm{Wt} / \mathrm{Lt}$ relationship was lower than 3 for males and greater for females of both species ("t" test, $\mathrm{p}<0.01$ ), indicating a negative and positive allometric growth for males and females respectively (Fig. 1a).

\section{Growth}

Growth studies of $F$. brasiliensis and F. paulensis were based on the length frequency distributions. The species were analyzed separately by sex, and later, the data for males and females were grouped for each species. This procedure was adopted because, although we could suppose a differentiated growth between the sexes, we needed to obtain mean values for the populations of the two species and for the stock as a whole, since the trawler fleet cannot accomplish the selective capture of the two resources.

Notwithstanding evidence in the literature regarding the existence of seasonal variations in growth (Garcia \& Le Reste, 1986), the parameters WP (winter point, which determines the period of the year when growth is slower) and $\mathrm{C}$ (a factor that expresses the amplitude of the oscillations), which define the seasonal oscillation in the growth curve, were fixed at zero, since we did not have information on the period and the causes of this oscillation.

From the data on length frequency, it was clear that the cohort recruited to the stock in May came from the December spawning of $F$. brasiliensis and November for $F$. paulensis. These months presented a higher number of mature females in landings from July, 1999 until July, 2001 from trawling by a fishing fleet based in Santos/Guarujá-SP (Leite Jr., 2001; Leite Jr. \& Petrere Jr., submitted). Thus, the growth curve was adjusted going through the modal groups that represented these cohorts.
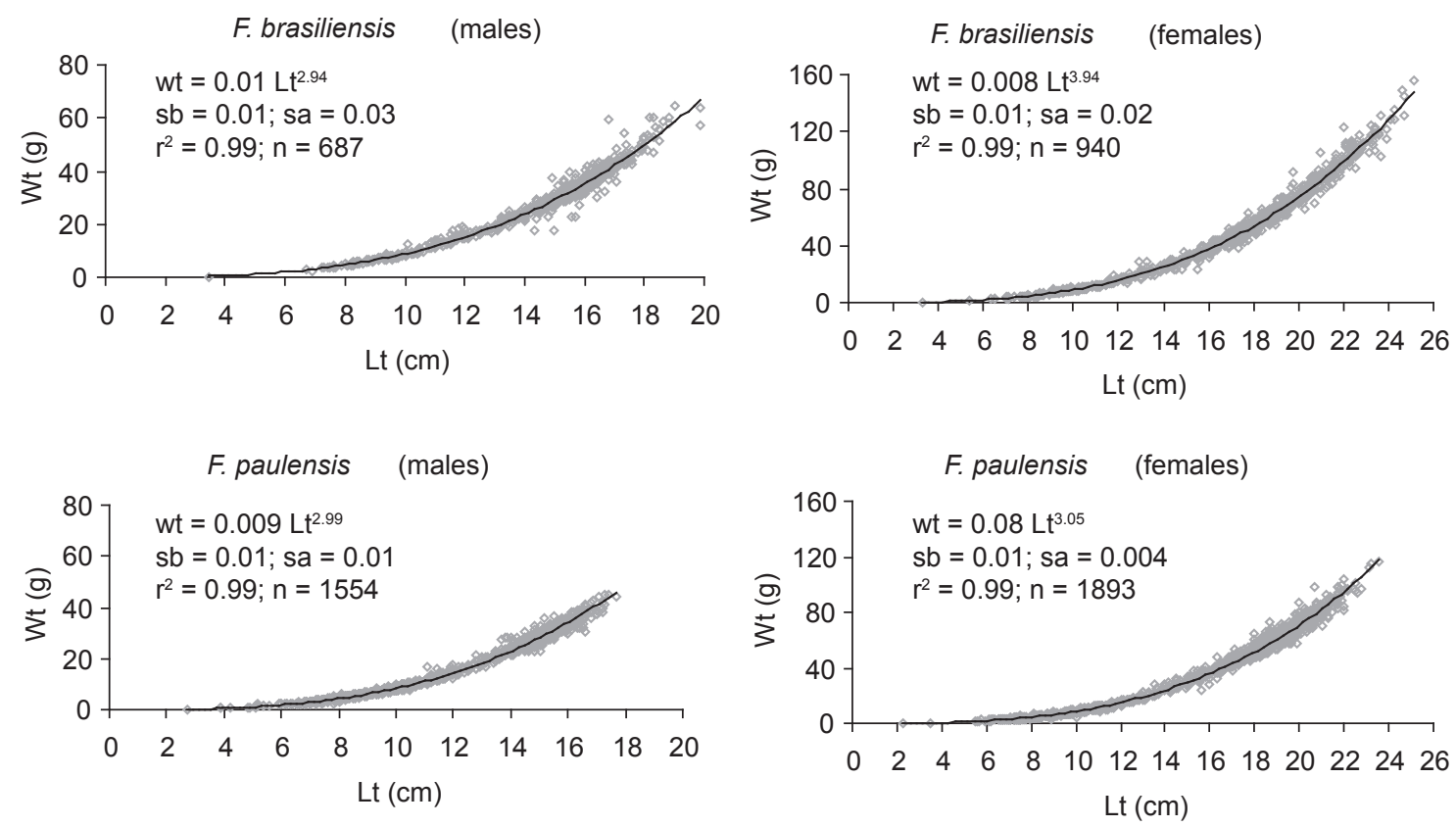

Fig. 1a - Total weight (Wt)/Total length (Lt) relationship for Farfantepenaeus brasiliensis and F. paulensis separated by sexes from June/1999 to June/2001. 

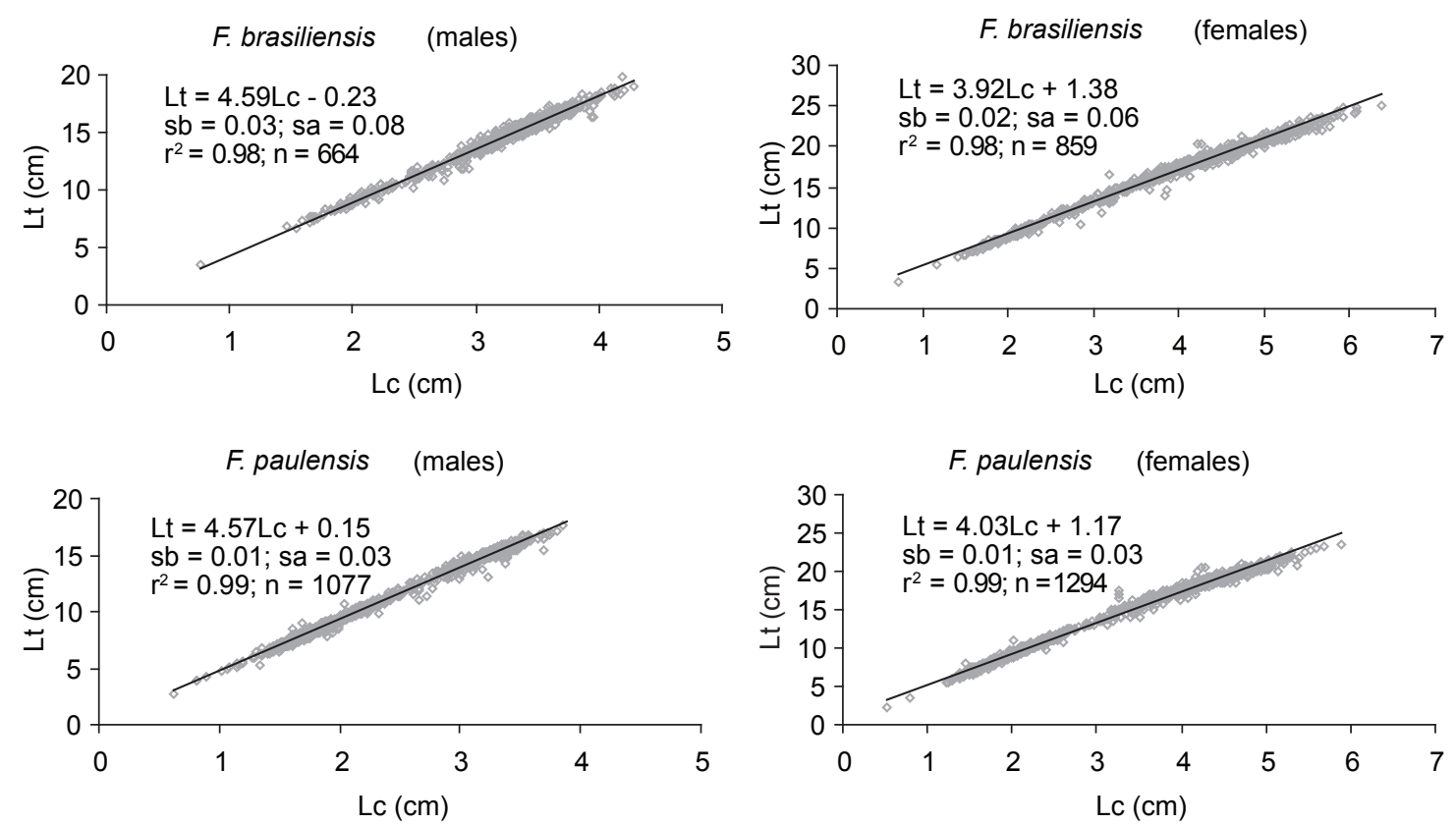

Fig. 1b - Total length (Lt)/Carapace length (Lc) relationship for Farfantepenaeus brasiliensis and F. paulensis separated by sexes from June/1999 to June/2001.

Figs $2 \mathrm{a}$ and $2 \mathrm{~b}$ show the restructured length frequencies and the results of the best fits found by Elefan-I (Pauly \& David, 1981), for data of males, females and combined sexes of both species. As expected, the asymptotic length $(L \infty)$ of the females was always larger than that of the males, a common pattern for the species of the family Penaeidae (Garcia \& Le Reste, 1986). The values of the growth coefficient $(\mathrm{k})$ were: 0.84 year $^{-1}$ for males, 0.9 year $^{-1}$ for females and 1.24 year $^{-1}$ for combined sexes for $F$. brasiliensis; and 0.83 year $^{-1}$ for males, 1.10 year $^{-1}$ for females and 1.34 year $^{-1}$ for combined sexes for $F$. paulensis (Table 1).

\section{Total mortality rate $(Z)$}

\section{Hoenig empirical method}

This method correlates the species longevity with its mortality (Sparre \& Venema, 1997). Although the authors did not include crustacean data in their empirical equation, this formula was used with the aim of comparing the results with those of other methods. Perhaps because of this fact, $\mathrm{Z}$ values obtained by this method may be sub- estimated (Table 2) and, thus were not included in the calculation of the mean $\mathrm{Z}$ for the species.

\section{Methods based on the mean length at capture}

Three methods estimated $\mathrm{Z}$ from the mean catch length: Beverton \& Holt (1956), Ault \& Ehrhardt (1991) and Ssentongo \& Larkin (1973). $\mathrm{Z}$ values obtained from these methods are presented in Table 2.

\section{Powell-Wetherall method}

This method gives an estimate of $\mathrm{Z} / \mathrm{K}$ (Powell 1979). The correspondent $Z$ values for the $k$ values obtained by Elefan-I are presented in Table 2.

\section{Catch curve method}

The catch curve is a graphical representation of the logarithm of the number of survivors of an age class (or of length) compared to the age. The slope of the straight line which links the descending points of the catch curve, with a changing sign, is an estimate of $\mathrm{Z}$ (Table 2) (Pauly, 1983). The probabilities of the capture of the classes corresponding to the ascending arm of the catch curve were also estimated. It was observed that in all 

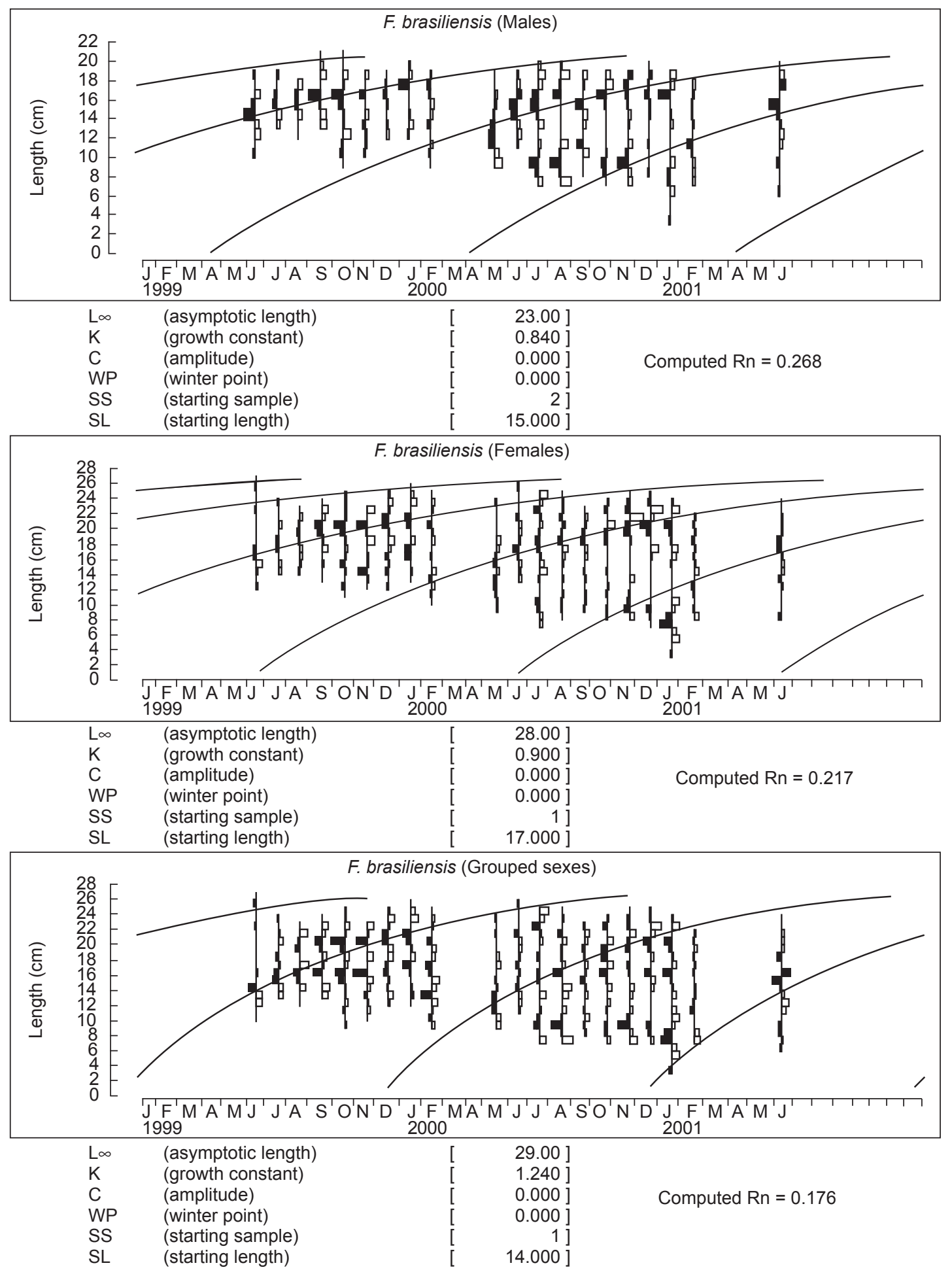

Fig. 2a - Restructured length frequency distributions, length growth parameters and fit index (Rn) estimated by ELEFAN-I for Farfantepenaeus brasiliensis for the industrial fisheries data. 

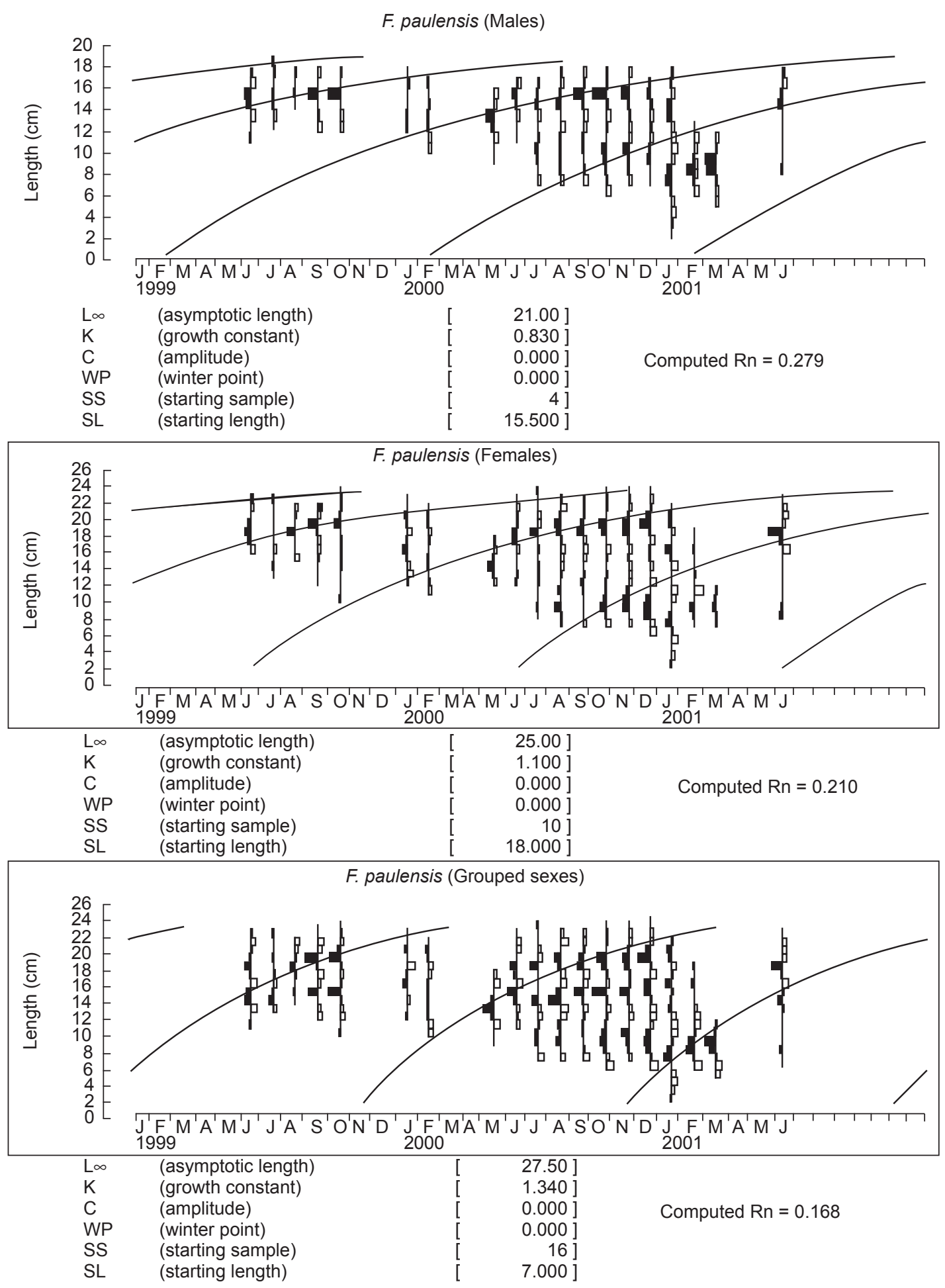

Fig. $2 \mathbf{b}-$ Restructured length frequency distributions, length growth parameters and fit index (Rn) estimated by ELEFAN-I for Farfantepenaeus paulensis for the industrial fisheries data. 
TABLE 1

Growth parameters ( $\mathrm{L}_{\infty}$ and $\left.\mathrm{K}\right)$ estimates by Elefant-I, for the Pink-Shrimps (Farfantepenaeus brasiliensis and $F$. paulensis).

\begin{tabular}{|l|l|l|l|c|}
\hline \multicolumn{1}{|c|}{ Species } & \multicolumn{1}{|c|}{ Data } & Sex & Lo $(\mathbf{c m})$ & K (year $\left.{ }^{-1}\right)$ \\
\hline \multirow{4}{*}{ F. brasiliensis } & Frequency distributions & Males & 23.0 & 0.84 \\
\cline { 2 - 5 } & Frequency distributions & Females & 28.0 & 0.9 \\
\cline { 2 - 5 } & Frequency distributions & Grouped sexes & 29.0 & 1.24 \\
\hline \multirow{3}{*}{ F. paulensis } & Frequency distributions & Males & 21.0 & 0.83 \\
\cline { 2 - 5 } & Frequency distributions & Females & 25.0 & 1.1 \\
\cline { 2 - 5 } & Frequency distributions & Grouped sexes & 27.5 & 1.34 \\
\hline
\end{tabular}

cases, the cumulative curves of capture probability increase rapidly from zero to $100 \%$, resembling the knife-edge model, with few length classes.

\section{The Jones and van Zalinge method}

This method estimated the total mortality by the cumulative catch curve (Jones \& van Zalinge, 1981). The $Z$ values estimated by this method are presented in Table 2.

\section{Natural mortality rate $(M)$}

\section{The Pauly empirical method}

The empirical equation of Pauly (1980) relates $\mathrm{M}$ to the temperature and growth parameters $(\mathrm{L} \infty$ and $\mathrm{K})$. The values calculated in this study used the estimate of L $\infty$ and $k$ obtained by Elefan-I and the mean annual temperature of $20^{\circ} \mathrm{C}$ obtained by Castro \& Miranda (1998) for the latitudes $23^{\circ}$ to $28^{\circ} 40^{\prime}$ (Table 3).

\section{Fishing mortality rate $(\mathrm{F})$}

The fishing mortality rate $(\mathrm{F})$, was estimated by the formula $\mathrm{F}=\mathrm{Z}-\mathrm{M}$, from mean $\mathrm{Z}$ and $\mathrm{M}$ values estimated from the above described methods. $\mathrm{F}$ values for both species are presented in Table 4 . Survival rates (S), in percentage, calculated from the formula $\mathrm{S}=\left(\mathrm{e}^{\mathrm{Z}}\right) \times 100$, varied from $0.02 \%$ and $1.4 \%$ (Table 4 ).

\section{DISCUSSION}

\section{Biometrical relationships}

The maximum total lengths obtained for the industrial fishery, for both species, are similar to those found by Pérez-Farfante (1988) in the Atlantic Ocean. The condition coefficient "b" of the $\mathrm{Wt} / \mathrm{Lt}$ relationship for males of both species showed negative allometric growth and it was proportionally bigger in length than in weight. The females presented positive allometric growth, indicating higher growth in weight than in length (Tesh, 1968). This result differs from the achieved one by Mello (1973) that found coefficients lower than 3 for males and females of $F$. paulensis, and Zenger Jr. \& Agnes (1977) for both species. Many other authors found a negative allometric growth for $F$. Brasiliensis and F. paulensis in most of the analyzed cases (Arreguín-Sanches, 1981; Villela et al., 1997; Branco \& Verani, 1998a; Albertoni et al., 2003). Branco \& Verani (1998b) found coefficients higher than 3 for males and lower for females of $F$. brasiliensis. D'Incao \& Calazans (1978) found coefficients higher than 3 in both sexes of $F$. paulensis. The positive allometric growth presented by the females in this study can be associated with the profit in weight due to the gonad development from the collected individuals which were proceeding mainly from adult stock fishing by the industrial fleet in the open sea.

\section{Growth}

Peneidae shrimps are individuals of fast and discontinuous growth because of moulting. However, due to the lack of synchronism and high frequency of moult per year, we can use a continuous growth model such as the von Bertalanffy model (von Bertalanffy, 1938; Garcia \& Le Reste, 1986).

The growth parameters, for both species, for males and females are numerically different, especially in relation to $\mathrm{L} \infty$, which was 23 and $21 \mathrm{~cm}$ for males and 28 and $25 \mathrm{~cm}$ for females of F. brasiliensis and F. paulensis, respectively. The estimated $\mathrm{L}_{\infty}$ for both species was numerically higher than those estimated by D'Incao (1984) for $F$. paulensis, and by Arreguín-Sánches (1981) and Villela et al. (1997), for F. brasiliensis and by Mello (1973) for both species (Table 5). 
TABLE 2

Total mortality estimated for the Pink- Shrimps (Farfantepenaeus brasiliensis and F. paulensis) using different methods. Estimated values calculated by Hoenig's method were excluded when calculating means.

\begin{tabular}{|c|c|c|c|c|}
\hline Species & Data & Method & Sex & $Z\left(\right.$ year $\left.^{-1}\right)$ \\
\hline- & $\operatorname{tmax}=2.0$ years & Hoenig & - & 2.13 \\
\hline- & $\operatorname{tmax}=2.5$ years & Hoenig & - & 1.71 \\
\hline- & $\operatorname{tmax}=3.0$ years & Hoenig & - & 1.43 \\
\hline \multirow{18}{*}{ F. brasiliensis } & Catch mean length & Beverton \& Holt & males & 4.84 \\
\hline & Catch mean length & Ault \& Ehrhardt & males & 4.83 \\
\hline & Catch mean length & Ssentongo \& Larkin & males & 5.24 \\
\hline & Length frequency & Powell-Wetherall & males & 4.67 \\
\hline & Catch curve & Pauly & males & 5.40 \\
\hline & Length frequency & Jones \& van Zalinge & males & 6.66 \\
\hline & Catch mean length & Beverton \& Holt & females & 4.07 \\
\hline & Catch mean length & Ault \& Ehrhardt & females & 4.06 \\
\hline & Catch mean length & Ssentongo \& Larkin & females & 4.49 \\
\hline & Length frequency & Powell-Wetherall & females & 4.34 \\
\hline & Catch curve & Pauly & females & 4.06 \\
\hline & Length frequency & Jones \& van Zalinge & females & 4.61 \\
\hline & Catch mean length & Beverton \& Holt & Grouped sexes & 6.47 \\
\hline & Catch mean length & Ault \& Ehrhardt & Grouped sexes & 6.46 \\
\hline & Catch mean length & Ssentongo \& Larkin & Grouped sexes & 7.06 \\
\hline & Length frequency & Powell-Wetherall & Grouped sexes & 6.02 \\
\hline & Catch curve & Pauly & Grouped sexes & 7.02 \\
\hline & Length frequency & Jones \& van Zalinge & Grouped sexes & 5.84 \\
\hline \multirow[t]{18}{*}{ F. paulensis } & Catch mean length & Beverton \& Holt & males & 5.31 \\
\hline & Catch mean length & Ault \& Ehrhardt & males & 5.30 \\
\hline & Catch mean length & Ssentongo \& Larkin & males & 5.71 \\
\hline & Length frequency & Powell-Wetherall & males & 5.94 \\
\hline & Catch curve & Pauly & males & 6.60 \\
\hline & Length frequency & Jones \& van Zalinge & males & 8.33 \\
\hline & Catch mean length & Beverton \& Holt & females & 4.81 \\
\hline & Catch mean length & Ault \& Ehrhardt & females & 4.80 \\
\hline & Catch mean length & Ssentongo \& Larkin & females & 5.34 \\
\hline & Length frequency & Powell-Wetherall & females & 6.21 \\
\hline & Catch curve & Pauly & females & 4.81 \\
\hline & Length frequency & Jones \& van Zalinge & females & 4.43 \\
\hline & Catch mean length & Beverton \& Holt & Grouped sexes & 8.85 \\
\hline & Catch mean length & Ault \& Ehrhardt & Grouped sexes & 8.84 \\
\hline & Catch mean length & Ssentongo \& Larkin & Grouped sexes & 9.49 \\
\hline & Length frequency & Powell-Wetherall & Grouped sexes & 7.47 \\
\hline & Catch curve & Pauly & Grouped sexes & 9.77 \\
\hline & Length frequency & Jones \& van Zalinge & Grouped sexes & 7.66 \\
\hline \multirow[t]{3}{*}{ F. brasiliensis } & \multicolumn{2}{|c|}{ mean } & males & 5.27 \\
\hline & \multicolumn{2}{|c|}{ mean } & females & 4.27 \\
\hline & \multicolumn{2}{|c|}{ mean } & grouped sexes & 6.48 \\
\hline \multirow[t]{3}{*}{ F. paulensis } & \multicolumn{2}{|c|}{ mean } & males & 6.20 \\
\hline & \multicolumn{2}{|c|}{ mean } & females & 5.07 \\
\hline & \multicolumn{2}{|c|}{ mean } & grouped sexes & 8.68 \\
\hline- & \multicolumn{2}{|c|}{ Average mean (excluded Hoenig's Method) } & - & 5.99 \\
\hline
\end{tabular}


TABLE 3

Natural mortality estimated (M), for the Pink-Shrimps (Farfantepenaeus brasiliensis and F. paulensis) using Pauly empiric method.

\begin{tabular}{|c|l|c|c|}
\hline \multicolumn{1}{|c|}{ Species } & \multicolumn{1}{|c|}{ Data } & Sex & M (year ${ }^{-1}$ ) \\
\hline \multirow{5}{*}{ F. brasiliensis } & $\mathrm{L} \infty=23 ; \mathrm{K}=0.84 ; \mathrm{T}=20^{\circ} \mathrm{C}$ & Males & 1.47 \\
\cline { 2 - 4 } & $\mathrm{L} \infty=28 ; \mathrm{K}=0.9 ; \mathrm{T}=20^{\circ} \mathrm{C}$ & Females & 1.45 \\
\cline { 2 - 4 } & $\mathrm{L} \infty=29 ; \mathrm{K}=1.24 ; \mathrm{T}=20^{\circ} \mathrm{C}$ & Grouped sexes & 1.78 \\
\hline \multirow{3}{*}{ F. paulensis } & $\mathrm{L} \infty=21 ; \mathrm{K}=0.83 ; \mathrm{T}=20^{\circ} \mathrm{C}$ & Males & 1.49 \\
\cline { 2 - 4 } & $\mathrm{L} \infty=25 ; \mathrm{K}=1.1 ; \mathrm{T}=20^{\circ} \mathrm{C}$ & Females & 1.71 \\
\cline { 2 - 4 } & $\mathrm{L} \infty=27.5 ; \mathrm{K}=1.34 ; \mathrm{T}=20^{\circ} \mathrm{C}$ & Grouped sexes & 1.89 \\
\hline F. brasiliensis & Mean & - & 1.57 \\
\hline F. paulensis & Mean & - & 1.70 \\
\hline \multirow{2}{*}{-} & Average mean & - & \\
\hline
\end{tabular}

TABLE 4

Estimates of total (Z), natural (M) and fishing (F) mortalities and survival rates (S) for the Pink-Shrimps (Farfantepenaeus brasiliensis and $\boldsymbol{F}$. paulensis).

\begin{tabular}{|c|l|c|c|c|c|}
\hline Species & \multicolumn{1}{|c|}{ Sex } & $\mathbf{Z}\left(\right.$ year $\left.^{-1}\right)$ & $\mathbf{M}\left(\right.$ year $\left.^{-1}\right)$ & $\mathbf{F}\left(\right.$ year $\left.^{-1}\right)$ & S (\%) \\
\hline \multirow{3}{*}{ F. brasiliensis } & Males & 5.3 & 1.5 & 3.8 & 0.51 \\
\cline { 2 - 6 } & Females & 4.3 & 1.5 & 2.8 & 1.40 \\
\cline { 2 - 6 } & Grouped sexes & 6.5 & 1.8 & 4.7 & 0.15 \\
\hline \multirow{3}{*}{ F. paulensis } & Males & 6.2 & 1.5 & 4.7 & 0.20 \\
\cline { 2 - 6 } & Females & 5.1 & 1.7 & 3.4 & 0.63 \\
\cline { 2 - 6 } & Grouped sexes & 8.7 & 1.9 & 6.8 & 0.02 \\
\hline Average mean & - & 6.0 & 1.7 & 4.3 & 0.25 \\
\hline
\end{tabular}

According to D'Incao (1984), the results reported by Mello (1973) for both species in southeast Brazil might be under-estimated, as his sampling period (1965 to 1969) coincided with an increase of the state of São Paulo fishing fleet, and so with an increase in the fishing effort. These observations might be associated to a reduced chance of the species reaching adult age and, thus, to a decrease in the individual lengths when being captured. Data obtained by Villela et al. (1997) for $F$. brasiliensis, in Araruama Lagoon/RJ, were lower than those obtained in the present study, owing to the fact that samples were restricted to juvenile individuals. The L $\infty$ estimated by D'Incao (1984) for F. paulensis is quite similar to the value obtained in the present study. Numerically the value is lower, perhaps due to the fact that the sampling efforts conducted by the author were restricted to the interior of the Patos lagoon (RS). The L $\infty$ values found by Arreguín-Sánches (1981), for $F$. brasiliensis in the Atlantic coast of Mexico are numerically similar to those obtained in the present study.

The $\mathrm{k}$ values had a smaller variation, between 0.83 and 1.67 year $^{-1}$ for the two species, being below the minimum limit of 1.8 year $^{-1}$ considered by Garcia \& Le Reste (1986). In comparison with the results obtained by D'Incao (1984) for $F$. paulensis, k values were smaller for males and larger for females. Results obtained by Mello (1973) for both species and by Arreguín-Sánches (1981) for F. brasiliensis, showed larger k values for both sexes in the two species. The values of $\mathrm{k}$ were inside the interval of values obtained by Villela et al. (1997) for F. brasiliensis (Table 5). The estimated parameters, for both species, 
TABLE 5

Comparison between growth parameters $\mathrm{L} \infty(\mathrm{cm})$ and $\mathrm{K}$ (year $\left.{ }^{-1}\right)$ in this study and the estimated from literature in different localities of study, for the Pink-Shrimps (Farfantepenaeus brasiliensis and F. paulensis). Values between brackets are the maximum length for the species.

\begin{tabular}{|c|c|c|c|c|c|c|}
\hline \multicolumn{7}{|c|}{$\mathbf{L} \infty(\mathbf{c m})$} \\
\hline Species & Sex & $\begin{array}{c}\text { Present } \\
\text { study (SP) }\end{array}$ & $\begin{array}{c}\text { D'Incao } \\
\text { (1984) (RS) }\end{array}$ & $\begin{array}{c}\text { Mello } \\
\text { (1973) (SP) }\end{array}$ & $\begin{array}{l}\text { Arreguín-Sánches } \\
\text { (1981) (Mexico) }\end{array}$ & $\begin{array}{l}\text { Villela et al. } \\
(1997)(\text { RJ) }\end{array}$ \\
\hline \multirow[t]{3}{*}{ F. brasiliensis } & Male & $23.0(21.9)$ & - & 17.6 & 21.9 & - \\
\hline & Female & $28.0(26.0)$ & - & 20.5 & 26.6 & - \\
\hline & Grouped sexes & 29.0 & - & - & - & 12.61 a 13.83 \\
\hline \multirow[t]{2}{*}{ F. paulensis } & Male & $21.0(18.0)$ & 19.3 & 16.5 & - & - \\
\hline & Female & $25.0(23.6)$ & 24.8 & 21.5 & - & - \\
\hline \multicolumn{7}{|c|}{ K $\left(\right.$ year $\left.^{-1}\right)$} \\
\hline Species & Sex & $\begin{array}{c}\text { Present } \\
\text { study (SP) }\end{array}$ & $\begin{array}{c}\text { D'Incao } \\
\text { (1984) (RS) }\end{array}$ & $\begin{array}{c}\text { Mello } \\
\text { (1973) (SP) }\end{array}$ & $\begin{array}{l}\text { Arreguín-Sánches } \\
\text { (1981) (Mexico) }\end{array}$ & $\begin{array}{l}\text { Villela et al. } \\
\text { (1997) (RJ) }\end{array}$ \\
\hline \multirow[t]{3}{*}{ F. brasiliensis } & Male & 0.84 & - & 1.62 & 3.01 & - \\
\hline & Female & 0.90 & - & 2.52 & 2.05 & - \\
\hline & Grouped sexes & 1.24 & - & - & 3.32 & 1.2 a 1.7 \\
\hline \multirow[t]{2}{*}{ F. paulensis } & Male & 0.83 & 1.25 & 1.12 & - & - \\
\hline & Female & 1.10 & 1.03 & 2.40 & - & - \\
\hline
\end{tabular}

for the combined sexes, were very close to the values obtained for females, probably due to the preponderance of females in the samples.

In penaeids, males have lower $\mathrm{L} \infty$ and higher $\mathrm{k}$ than females (Garcia \& Le Reste, 1986; Dall et al., 1990) in this study, growth parameters of males and females of $F$. brasiliensis are compatible with this information. Males of $F$. paulensis presented lower values of $\mathrm{L} \infty$ and $\mathrm{k}$ than females. According to Pauly et al. (1984) the annual k could vary from 0.25 to 2.5 years $^{-1}$ and longevity from 1.5 to 2.5 years in penaeids (Garcia \& Le Reste, 1986). The growth parameters estimated in the present study are compatible with published information available for both species.

\section{Mortality}

The estimated mean values of $\mathrm{Z}$ for both species, 5.3 year $^{-1}$ (males), 4.3 year $^{-1}$ (females) and
6.5 year $^{-1}$ (combined sexes) for F. brasiliensis and 6.2 year $^{-1}$ (males), 5.1 year $^{-1}$ (females) and 8.7 year $^{1}$ (combined sexes) for $F$. paulensis, were similar to the estimated values in the literature for heavily exploited stocks. Pauly, Ingles \& Neal (1984 apud Isaac et al.,1992) reported values of 5.43 and 6.71 year $^{-1}$ for males and females of Litopenaeus setiferus Pérez-Farfante, 1969 in Texas/USA and 7.07 year $^{-1}$ for Farfantepenaeus duorarum Burkenroad, 1939 in Flórida/USA. In a revision of various penaeidean from Africa, Australia and the Gulf of Mexico, Garcia (1985) reported a mean total mortality around 4 years $^{-1}$. D'Incao (1984) found $\mathrm{Z}$ values of 7.80 and 6.84 year $^{-1}$ for males and females of $F$. paulensis in the estuary of Patos Lagoon/RS and Villela et al. (1997) found values between 9.22 and 9.44 year $^{-1}$ for $F$. brasiliensis in Araruama Lagoon/RJ. 
There are many procedures to calculate the natural mortality rate (M). However, all of these procedures are highly doubtful in their theoretical implications and, in most cases, they just allow an approximate estimate or an intelligent guess (Sparre \& Venema, 1997).

The $M$ values obtained in this study were estimated using Pauly's empirical method (1980). This formulae is derived from data of fish stocks and Pauly's empirical method was used by Isaac et al. (1992), for Farfantepenaeus subtitilis Pérez-Farfante, 1967, with the results being similar to those obtained from the regression between the total mortality and effort. Isaac et al. (1992) highlight that, although the estimated values obtained from empirical equations should be considered as an approximation of the true $M$ value, these methodologies are widely used in the fishery literature, as more precise methods are not available yet or have unviable applications. Within this context, the values obtained from Pauly's empirical model (1980) were used in all of the subsequent models that used the natural mortality rate as input data.

Garcia \& Le Reste (1986) argued that, due to the high $\mathrm{k}$ values, penaeid shrimps would have equally high $\mathrm{M}$ values. The mean $\mathrm{M}$ values obtained in this study for $F$. brasiliensis and $F$. paulensis were of 1.8 and 1.9 year $^{-1}$, respectively. In Garcia's above mentioned revision (Garcia, 1985), the mean $M$ value was 2.4 year $^{-1}$, ranging from 1.8 to 2.5 year $^{-1}$ for Farfantepenaeus aztecus Ives, 1891, 2.2 year $^{-1}$ for Litopenaeus setiferus Pérez-Farfante, 1969, 2.5 to 3.0 year 1 for Farfantepenaeus notialis Pérez-Farfante, 1967, 2.5 year $^{-1}$ for Fenneropenaeus indicus Milne Edwards, 1837 and 2.4 year $^{-1}$ for Melicertus sp. Rafinesque, 1814 and Fenneropenaeus merguiensis De Man, 1888. Estimates of M for $F$. paulensis were 1.56 and 1.32 year $^{-1}$ for males and females, respectively (D'Incao, 1984). Villela et al. (1997) found $\mathrm{M}$ values between 2.08 and 2.41 year $^{-1}$ for $F$. brasiliensis in Araruama Lagoon/RJ. Notwithstanding the fact that all these values are approximations and subject to long-term seasonal changes, they seem to be coherent and within the same order of magnitude.

The $\mathrm{F}$ values for both species, 4.7 year $^{-1}$ for F. brasiliensis and 6.8 year $^{-1}$ for $F$. paulensis, were above the mean value (1.6 year $\left.{ }^{-1}\right)$ reported by Garcia
(1985) for highly exploited stocks. However, this author used $\mathrm{F}$ values, for the calculation of this mean value, ranging from 1.1 year $^{-1}$ to 12.0 year $^{1}$. The values obtained in the present study are within this wide interval. Using $\mathrm{Z}$ and $\mathrm{M}$ values estimated for F. paulensis by D'Incao (1984) for the artisanal fishery restricted to the Patos lagoon/RS, the $F$ values for this species were 6.24 year $^{-1}$ for males and 5.52 year $^{-1}$ for females. These values are higher that those found in the present (4.7 and 3.4 year $^{-1}$ for males and females, respectively) for the industrial fishery in the open sea, as well as higher than the value found by Villela et al. (1997) for F. brasiliensis in Araruama lagoon/RJ (7 year $\left.{ }^{-1}\right)$.

Natural mortality of small organisms like shrimps is always high and besides this, Penaeid shrimps are heavily exploited on the Brazilian coast and in all the seas of the world. Juveniles were fished in the estuaries and swallow waters by small trawlers and adults in the open sea by an industrial fleet. The estimated parameters of the present study show that pink-shrimps have short life cycles, fast growth, short longevity and high mortality rates and indicate that the fishery effect on the resource is very intense, leading to a low survival rate for both species. Several studies show that the pink-shrimp fishery is at its maximum sustainable yield (D'Incao et al., 2002; Valentini et al., 2001). So, it is necessary to implement administrative procedures in order to preserve the stock, like the immediate reduction in the fishing effort by reducing the fleet size, along with closed seasons and of some fishery areas to assure the recruitment of the species.

Acknowledgments - The authors acknowledge FAPESP (Processo $\mathrm{n}^{\circ}$ 99/06038-0), UNESP and CNPq for partially supporting of this research. We are indebted to IOUSP, UNESP (Brazil) and IP/SP for the use of their facilities and specially to Dr. Acácio Ribeiro Gomes Tomás.

\section{REFERENCES}

ALBERTONI, E. F., PALMA-SILVA, C. \& ESTEVES, F. A., 2003, Crescimento e fator de condição na fase juvenil de Farfantepenaeus brasiliensis (Latreille) e F. Paulensis (Pérez-Farfante) (Crustacea, Decapoda, Penaeidae) em uma lagoa costeira tropical do Rio de Janeiro, Brasil. Revista Brasileira de Zoologia, 20(3): 409-418.

ALLEN, K. R., 1966, A method of fitting growth curves of the von-Bertalanffy type to observed data. J. Fish. Res. Board Can., 23: 163-179. 
ARREGUÍN-SÁNCHEZ, F., 1981, Tasa de crecimiento del camarón rojo, Penaeus brasiliensis Latreille, 1817, de las costas de Quintana Roo, México. Ciencia Pesquera. Inst. Nal. Pesca. Depto. Pesca. México, 1: 61-70.

AULT, J. S. \& EHRHARDT, N. M., 1991, Correction to the Beverton and Holt Z-estimator for truncated match lengthfrequency distributions. ICLARM Fishbyte, 9: 37-39.

BHATTACHARYA, C. G., 1967, A Simple method of resolution of a distribution into Gaussian components. Biometrics, 23: $115-135$.

BEVERTON, R. J. H. \& HOLT, S. J., 1956, A review of methods for estimating mortality rates in exploited fish populations, with special reference to sources of bias in catch sampling. Rapp. P. -v. Reún. Cons. Perm. Int. Explor. Mer, 140: 67-83.

BRANCO, J. O. \& VERANI, J. R., 1998a, Aspéctos bioecologicos do camarão-rosa Penaeus brasiliensis Latreille (Natantia, Penaeidae) da Lagoa da Conceição, Florianópolis, Santa Catarina, Brasil. Revista Brasileira de Zoologia, 15(2): 345-351.

BRANCO, J. O. \& VERANI, J. R. 1998b, Estudo populacional do camarão-rosa Penaeus paulensis Pérez-Farfante (natantia, penaeidae) da Lagoa da Conceição, florianópolis, Santa Catarina, Brasil. Revista Brasileira de Zoologia, 15(2): 353-364.

CASTRO, B. M. \& MIRANDA, L. B., 1998, Physical oceanography of the western Atlantic continental shelf located between $4^{\circ} \mathrm{N}$ and $34^{\circ} \mathrm{S}$ coastal segment $4^{\circ} \mathrm{W}$., pp. 65-87. In: A. R. Robinson \& K. H. Brink (eds.), The Sea. Cambridge: Cambridge University Press.

DALL, W., HILL, B. J., ROTHLISBERG, P. C. \& STAPLES, D. J., 1990, The biology of the Penaeidae, pp. 1-489. In: Blaxter J. H. S., Southward A. J. (Ed.). Advances in marine Biology. Academic Press, San diego.

D'INCAO, F. \& CALAZANS, D., 1978, Relações biométricas do "camarão-rosa" Penaeus paulensis Perez-Farfante, 1967, da Lagoa dos Patos, RS. Atlântica Rio Grande, 3: 57-66.

D'INCAO, F., 1984, Estudo sobre o crescimento de Penaeus,Farfantepeneus, paulensis Perez-Farfante, 1967 da Lagoa dos Patos, RS, Brasil, Decapoda, Penaeidae. Atlântica Rio Grande, 7: 73-84.

D'INCAO, F., 1995, Taxonomia, padrões distribucionais $e$ ecológicos dos Dendrobranchiata, Crustacea: Decapoda, do Brasil e Atlântico Ocidental. $\mathrm{PhD}$ Thesis, Universidade Federal do Paraná, Curitiba, 365p.

D'INCAO F., VALENTINI, H. \& RODRIGUES, L. F., 2002, Análise da pesca de camarões nas regiões Sudeste e Sul do Brasil. Atlântica, Rio Grande, 24(2): 103-116.

FAO, 1998, Yearbook Fishery Statistics Capture Production, 82: 371-381. 1996.

GARCIA, S., 1985, Reproduction, stock assessment models and population parameters in exploited penaeid shrimp populations, pp. 138-158. In: P.C. Rothlisberg, B. J. Hill and D. J. Staples (eds.), Second Australian National Prawn Seminar. Cleveland: Australia, NPS2.

GARCIA, S. \& LE RESTE, L., 1986, Ciclos vitales, dinámica, explotación y ordenación de las poblaciones de camarones peneidos costeros. FAO Doc. Téc. Pesca, 203: 180.
GAYANILO JR., F. C. P., SPARRE, P. \& PAULY, P., 1994, The FAO-ICLARM stock assessment tools, FiSAT, user's guide. FAO Computerized Information Series Fisheries, 7: 124.

GULLAND, J. A. \& HOLT, S. J., 1959, Estimation of growth parameters for data at unequal time intervals. J. Cons. CIEM 25: 47-49.

HOENIG, J. M., 1983, Empirical use of longevity data to estimate mortality rates. Fish. Bull., 81: 898-903.

IBAMA, 1997, Diretrizes Ambientais para o Setor Pesqueiro: Diagnóstico e Diretrizes para a Pesca Marítima. MMA, Brasília, Brasil, 124p. il.

ISAAC, V. J., DIAS-NETO, J. \& DAMASCENO, F. G., 1992, Camarão-rosa da costa norte: biologia e administração pesqueira. IBAMA. Brasília, Brasil. Coleção Meio Ambiente, Série Estudos-Pesca, 1: 187.

IWAI, M., 1973, Pesca Exploratória e Estudo Biológico sobre o Camarão na Costa Centro-Sul do Brasil do N/O "Prof. W. Besnard" em 1969-1971. Relatório de Pesquisa, Inst. Oceanogr., São Paulo.

JONES, R. \& VAN ZALINGE, N. P., 1981, Estimates of mortality rate and population size for shrimp in Kuwait waters. Kuw. Bull. of Mar. Sci., 2: 273-288.

LEITE JR., N. O. \& PETRERE JR., M., (submitted) Características biológicas do camarão-rosa Farfantepenaeus brasiliensis e Farfantepenaeus paulensis capturado pela frota industrial da região de Santos/Guarujá e artesanal em Cananéia, São Paulo, Brasil. Boletim do Instituto de Pesca, SP.

LEITE JR., N. O., 2001, Dinâmica Populacional do CamarãoRosa Farfantepenaeus brasiliensis e Farfantepenaeus paulensis da Região Sudeste do Brasil (23 a $\left.28^{\circ} \mathrm{S}\right)$. Universidade de São Paulo, Instituto Oceanográfico, Dissertação de Mestrado, 130p.

MELLO, J. T. C., 1973, Estudo populacional do camarãorosa, Penaeus brasiliensis,Latreille, 1817, e Penaeus paulensis Pérez-Farfante, 1967. Bol. Inst. Pesca, São Paulo, 2: 19-65.

NEIVA, S. G., WORSMANN, T. U., OLIVEIRA, M. T \& VALENTINI, H., 1971. Contribuição ao estudo da maturação da gônada feminina do "camarão rosa" (Penaeus paulensis Pérez Farfante, 1967). Bol. Inst. Pesca, 1(4): 23-38. São Paulo.

PAULY, D., 1980, On the interrelationships between natural mortality, growth parameters and mean environmental temperature in 175 fish stocks. J. Cons., Cons. Int. Explor. Mer, 39: 175-192.

PAULY, D., 1983, Some simple methods for the assessment of tropical fish stocks. FAO Fish. Tech. Pap., 234: 52.

PAULY, D. \& DAVID, N., 1981, ELEFAN-1, a BASIC program for the objective extraction of growth parameters from length-frequency data. Meeresforsch., 28: 205-211.

PAULY, D., INGLES, J. \& NEAL, R., 1984, Application to shrimp stocks of objective methods for the estimation of vital statistics from length data, pp. 58-69. In: J. A. Gulland and B. J. Rohschild (eds.), Penaeid Shrimps: Their Biology and Management.Farnham: Fishing News Books.

PEREZ, J. A. A., P. R. PEZZUTO, L. F. RODRIGUES, H. VALENTINI \& C. M. VOOREN, 2001. Relatório da 
reunião técnica de ordenamento da pesca de arrasto nas regiões Sudeste e Sul do Brasil. (7 a 11/5/2001), CEPESUL/ IBAMA, Itajaí, SC, 45p.

PÉREZ-FARFANTE, I., 1988, Illustrated key to penaeoid shrimps of commerce in the Americas. NOAA Technical Reports NMF, 64: 32.

POWELL, G. D., 1979, Estimation of mortality and growth parameters from the length frequency of a catch. Rapp. P.v. Réun. Cons. Int. Explor. Mer, 175: 167-169.

RUFFINO, M. L., 1991, Dinâmica populacional do camarão Artemesia longinaris BATE, 1988, Decapoda, Penaeidae, do sul do Brasil. MSc Dissertation, Fundação Universidade do Rio Grande, Rio Grande, 96p.

SNEDECOR, G. W. \& COCHRAN, W. G., 1967, Statistical Methods $6^{\text {th }}$. Ed., Ames:The Iowa State University Press, 593p.

SPARRE, P. \& VENEMA, S. C., 1997, Introdução à Avaliação de Mananciais de Peixes Tropicais. Parte 1: manual. FAO Documento Técnico sobre as Pescas, 306/1 Rev. 2: 404p.

SSENTONGO, G. W. \& LARKIN, P., 1973, Some simple methods of estimate mortality rates of exploited fish populations. J. Fish. Res. Board Can., 30: 695-698.
TESH, F. W. 1968, Age and growth, pp. 93-123. In: W. E. Richer (Ed.). Methods for Assessment of fish production in fresh waters. Oxford, Blackwell Scientific Publications, 313p.

VON BERTALANFFY, L., 1938, A quantitative theory of organic growth, inquiries on growth laws II. Hum. Biol., 10: 181-213.

VALENTINI, H., D'INCAO, F., RODRIGUES, F. L., NETO, J. E. R. \& RAHN, E., 1991, Análise da pesca do camarãorosa, Penaeus brasiliensis e Penaeus paulensis, nas regiões Sudeste e Sul do Brasil. Atlântica, Rio Grande, 13: 143-157.

VILELA, M. J., COSTA, P. A. S. \& VALENTINI, J. L., 1997, Crescimento e mortalidade de juvenis do camarão-rosa, Penaeus brasiliensis Latreille, 1817, na Lagoa de Araruama, Rio de Janeiro. Rev. Brasil. Biol., 57: 487-499.

ZAR, J. H., 1996, Bioestatistical analysis. $3^{\text {th }}$ Ed.Upper Sadle River: Prentice Hall, 662p.

ZENGER JR., H. H. \& AGNES J. L., 1977, Distribuição do camarão-rosa Penaeus brasiliensis e Penaeus paulensis ao longo da costa sudeste e sul do Brasil. IBAMA. Brasília, Brasil, Ser. Doc. Tec., 21: 105p. 